\title{
Effect of Maternal Adrenalectomy and Corticosterone Therapy on the Early Development of B-Cells in the Fetal Pancreatic Islet in the Rat
}

\author{
Suguru KOMATSU, Masako YAMAMOTO, Tatsuya TAKIZAWA ${ }^{1)}$, Mitsuyuki SHIRAI ${ }^{2)}$, Kazuyoshi ARISHIMA, and \\ Yasunobu EGUCHI \\ Departments of Anatomy II, "Developmental Biotechnology, and ${ }^{2)}$ Veterinary Pharmacology, Azabu University, School of Veterinary \\ Medicine, 1-17-71 Fuchinobe, Sagamihara-shi, Kanagawa 229, Japan
}

(Received 28 March 1996/Accepted 24 June 1996)

ABSTRACT. Pregnant Wistar rats were divided into 3 groups, non-operated control, adrenalectomized, and adrenalectomized and corticosterone-treated. Maternal adrenalectomy was performed on day 6 of gestation. Corticosterone therapy was made from the day at operation to the day at observation. The growth pattern of insulin-producing B-cells was observed immunohistochemically and histometrically from days 12 to 16 . The results obtained were as follows: From day 12 to day 15 , maternal adrenalectomy resulted in a significant retardation of the growth of insulin-positive B-cells in terms of the collective volume of the cells. Maternal corticosterone therapy prevented this retardation. On day 16, however, the growth of B-cells in collective volume overcame the suppressive effect of maternal adrenalectomy. These results suggest that the lack of adrenocortical hormones causes a retardation of B-cell growth in early development, and that, when once developed well, B-cells can grow independently of the hormones. - KEY wORDs: adrenalectomy, B-cell, corticosterone, fetal rat, islet.

J. Vet. Med. Sci. 58(10): 995-999, 1996

In rat fetuses, the pancreas develops first as the dorsal bud protruding from the gut on day 11 of gestation, soon followed by the growth of the ventral bud $[6,12]$. The pancreas consists of the endocrine and the exocrine parts. The endocrine part is composed of the pancreatic islets which start as primitive cell-masses derived from epithelial cells of the exocrine duct system. The islets soon develop to contain glucagon-producing cells (A-cells) and insulinproducing cells (B-cells). A-cells first appear as early as on day 11 of gestation $[4,16]$, followed by the subsequent appearance of B-cells on day 12 [16].

It has been well known that adrenocortical hormones may participate in some different ways in development of many organs including pancreas during the prenatal period. For example, as to B-cells in the endocrine part, many studies have been performed with special emphasis on the role of adrenocortical hormones in organ culture system. The results obtained almost agree with each other in such a fashion that adrenocortical hormones exert no influence on the differentiation of these cells [13] and some inhibition on the insulin secretion from these cells [8-11]. It is unknown, however, whether these in vitro results can be the case in in vivo studies.

The present work was designed to assess the effects of maternal adrenocortical hormones in vivo on the development of fetal B-cells in the rat. In the present research design, pregnant rats were adrenalectomized as early as on day 6 of gestation to sustain their fetuses under no influence of transplacental maternal adrenocortical hormones. The observations are the first of their kind in that maternal adrenalectomy is performed at so early a stage when even the fetal endocrine pancreatic anlage does not appear. By the time when pancreatic islets first appear, there would be present no more maternal hormones in fetal circulation in utero. Maternal hormonal therapies were performed with corticosterone administration.

\section{MATERIALS AND METHODS}

Wistar rats (CLEA, Tokyo) were given a commercial diet (Labo MR Breeder) and water both ad libitum. Females were placed with males overnight and the day on which sperm was detected in vaginal smear was designated as day 0 of gestation.

Pregnant rats were divided into 3 groups, non-operated (control group), adrenalectomized (ADX group), and adrenalectomized and corticosterone-treated group (ADX+cort group). Maternal adrenalectomy was performed on day 6 of gestation. Corticosterone (Sigma Chemical Co., St. Louis) was injected subcutaneously at a dose of 40 $\mathrm{mg} / \mathrm{kg}$ body weight once a day from the day at operation to the day at autopsy. Rats in both the ADX and the ADX+cort groups were given $0.9 \%$ saline solution as a drinking water. Maternal autopsy was made under ether anesthesia at 13:00 on each day from day 12 to day 16 of gestation. At autopsy, if adrenal remnants were found due to incomplete removal of the gland from its original sites, or if accessory adrenal tissue was discovered, the animals were not included in the series. Fetuses were quickly removed from the uteri of mother rats. On days 12 and 13 , each fetus was fixed in Bouin's fluid in toto. On days 14, 15 and 16, the fetal pancreas was removed together with the stomach and duodenum and was fixed in the same fluid. The fixedmaterials were then dehydrated in a graded series of ethanol, embedded in Paraplast (Sherwood Medical, St. Louis), and sectioned serially at $5 \mu \mathrm{m}$. The sections were 
immunostained with anti-insulin serum (Incstar, Stillwater, Minnesota). The outline of every insulin-positive cell in every section of the series was measured with an imageanalyser system (Image Command 5098, Olympus). The collective volume of insulin-positive cells in each pancreas was determined by the following formula:

\section{Collective volume $=$ sum of outline areas} $x$ thickness of section.

Analyses of the data were made with Duncan's new multiple range test. A p value less than 0.05 was considered significant statistically.

\section{RESULTS}

On day 12 , in the control group, many insulin-positive cells already existed in somewhat aggregated cell-masses in the wall of the pancreatic anlage (Fig. 1a). In the ADX group, the number of insulin-positive cells appeared to be reduced as compared with that in the control group (Fig. $1 \mathrm{~b}$ ), which is reflected in a significantly decreased collective volume of the cells as shown in Table 1. Histologically, the aggregated cell-masses apparently retarded in growth (cf. Figs. 1a and $1 \mathrm{~b}$ ). In the ADX+cort group, however, the situation was about the same as in the control group both histometrically (Table 1) and immunohisotochemically (Fig. 1c), though the aggregated cell-masses apparently turned to primitive islets.

On day 13 , overall results were almost the same as those on day 12 , accompanied by some increase in the collective volume of insulin-positive cells.

On day 14 , the aggregated cell-masses loaded with insulin-positive cells (primitive islets) were migrating into the mesenchyme from the relatively well-developed duct system as the exocrine part in which acini were formed here and there (Fig. 2a). Each insulin-positive cell appeared to be enlarged. The collective volume of insulin-positive cells was further increased (Table 1). In the ADX group, the insulin-positive cells were smaller in size (Fig. 2b) and in collective volume (Table 1) than those in the control group. In the $\mathrm{ADX}+\mathrm{cort}$ group, in contrast, histological observation showed a pattern similar to that in the control group (Fig. 2c). The collective volume of insulin-positive cells approximated to that in the control group (Table 1).

On day 15 , both the endocrine and the exocrine parts were markedly promoted in growth. Insulin-positive cells were located even in the duct system as well as in the islet system. In the ADX group, the insulin-positive cells were clearly decreased in number histologically as well as in collective volume histometrically, as compared with the control group (Table 1). In the ADX+cort group, however, the corticosterone therapy failed to compensate the decline of collective volume in view of statistics; the volume was not significantly different from that in the ADX group.

On day 16 , though the body weight of fetuses was increased almost 1.5 to 2 times as large as that on the foregoing day, the increment of the collective volume was so explosive that the growth rate was far higher than that of the body weight, the volume being approximately 7.5 to 10 times as large as that on the foregoing day. Histological observation showed that the distribution and number of insulin-positive cells in the islet were almost the same in

Table 1. Changes in fetal body weight and collective volume of insulin-positive cells with age in the control, $\mathrm{ADX}$, and $\mathrm{ADX}+\mathrm{cort}$ groups (mean $\pm \mathrm{SEM}$ )

\begin{tabular}{clccc}
\hline Age in days & Group & $\begin{array}{c}\text { No. of } \\
\text { samples }\end{array}$ & Body wt (mg) & $\begin{array}{c}\text { Collective volume of insulin- } \\
\text { positive cells }\left(\times 100 \mu \mathrm{m}^{3}\right)\end{array}$ \\
\hline 12 & Control & $11(4)$ & - & $7.8 \pm 0.9$ \\
& ADX & $13(3)$ & - & $3.3 \pm 0.8^{* *}$ \\
& ADX+cort & $13(4)$ & - & $7.0 \pm 0.8$ \\
13 & Control & $13(5)$ & - & $12.2 \pm 1.3$ \\
& ADX & $14(5)$ & - & $6.6 \pm 1.3 * *$ \\
& ADX+cort & $10(3)$ & - & $10.1 \pm 0.6$ \\
14 & Control & $13(3)$ & $159 \pm 4$ & $26.9 \pm 2.9$ \\
& ADX & $11(3)$ & $146 \pm 3$ & $17.3 \pm 2.0^{* *}$ \\
& ADX+cort & $10(3)$ & $150 \pm 7$ & $25.4 \pm 1.2$ \\
& & & & $46.8 \pm 5.0$ \\
& Control & $13(4)$ & $278 \pm 3$ & $29.9 \pm 4.3 *$ \\
& ADX & $9(3)$ & $285 \pm 13$ & $41.6 \pm 3.6$ \\
& ADX+cort & $13(4)$ & $292 \pm 5$ & $352.6 \pm 62.1$ \\
& & & & $308.5 \pm 41.3 \mathrm{~ns}$ \\
& Control & $10(3)$ & $447 \pm 12$ & $325.4 \pm 28.6$ \\
\hline
\end{tabular}

$*$ Significantly different only from the control group $(p<0.05) . *$ Significantly different from both the control and the ADX+cort groups $(p<0.05)$. ns=Not significantly different from both the control and the ADX+cort groups. Number of litters in parentheses. 


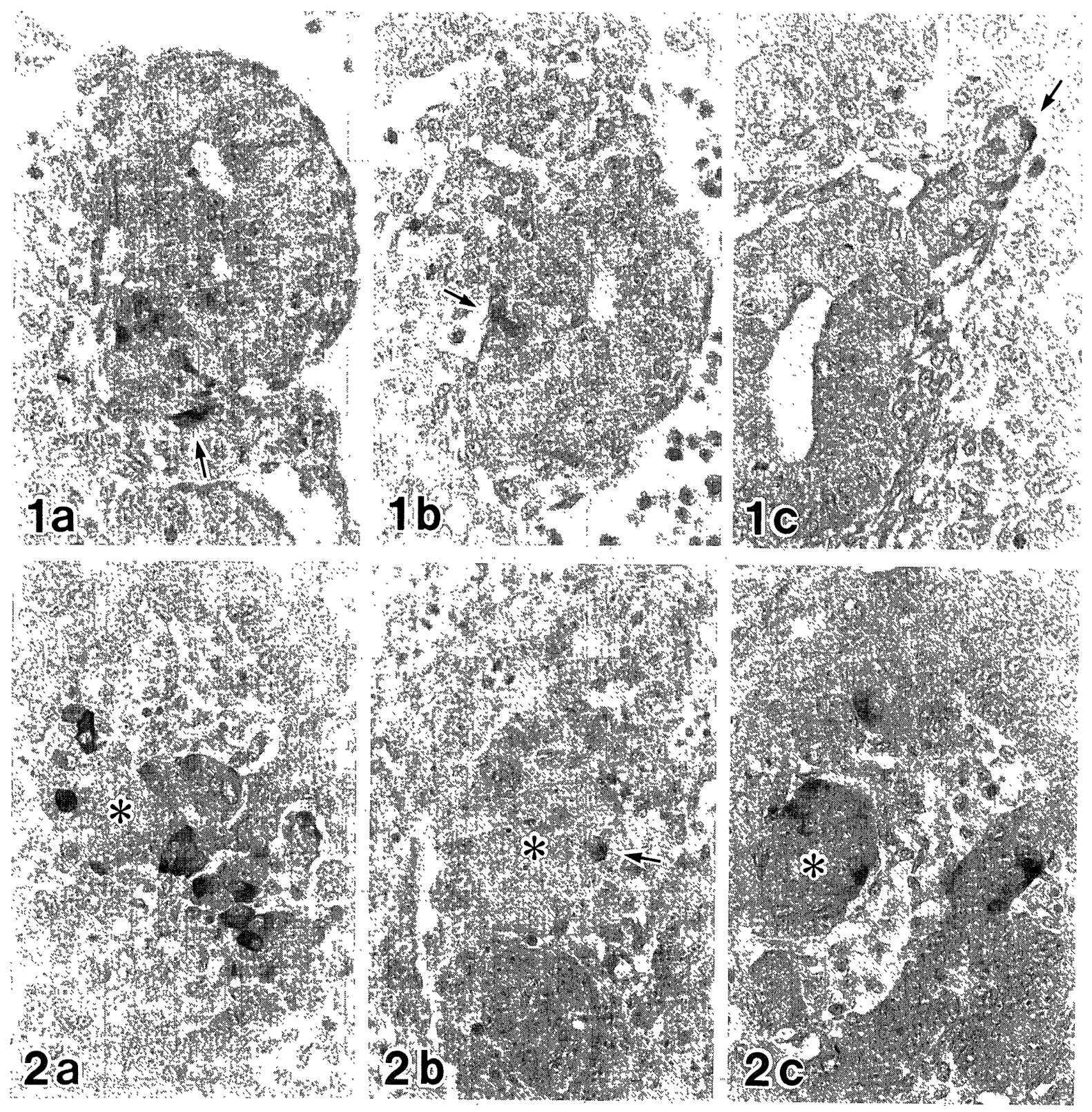

Fig. 1. Photomicrographs of 12-day fetal pancreases (a: control group, b: ADX group, c: ADX+cort group, $\times 333$ ). a: Insulinpositive cells (arrow) have appeared already. b: Insulin-positive cells are decreased in number as compared with those in the control group. c: Insulin-positive cells have developed similarly to those in the control group.

Fig. 2. Photomicrographs of 14-day fetal pancreases (a: control group, b: ADX group, c: ADX+cort group, $\times 333$ ). a: Most of the insulin-positive cells exist in the primitive islets (asterisk). b: Only a few insulin-positive cells are located in the primitive islets. c: Insulin-positive cells resemble those in the control group in size and stainability.

the 3 groups (Figs. 3a-c). Similarly, collective volumes of the cells were not significantly different among the 3 groups (Table 1).

\section{DISCUSSION}

In general, gene expressions seem to appear prior to the onset of morphogenesis in early development. For instance, some amount of insulin can be detected in the 11-day pancreatic bud, just before the appearance of B-cells [1].
The foregoing immunohistochemical observations revealed that insulin-positive B-cells existed in the fetal pancreatic anlage already on day 12 of gestation. This is also in line with an earlier report that insulin-mRNA is already present on day 12 [5].

It has been well documented that adrenocortical hormones can cross the placenta from the mother to the fetus and vice versa $[3,7,17]$. In the present study, therefore, pregnant rats were adrenalectomized as early as on day 6 of gestation the time when was far earlier than the time of the first 

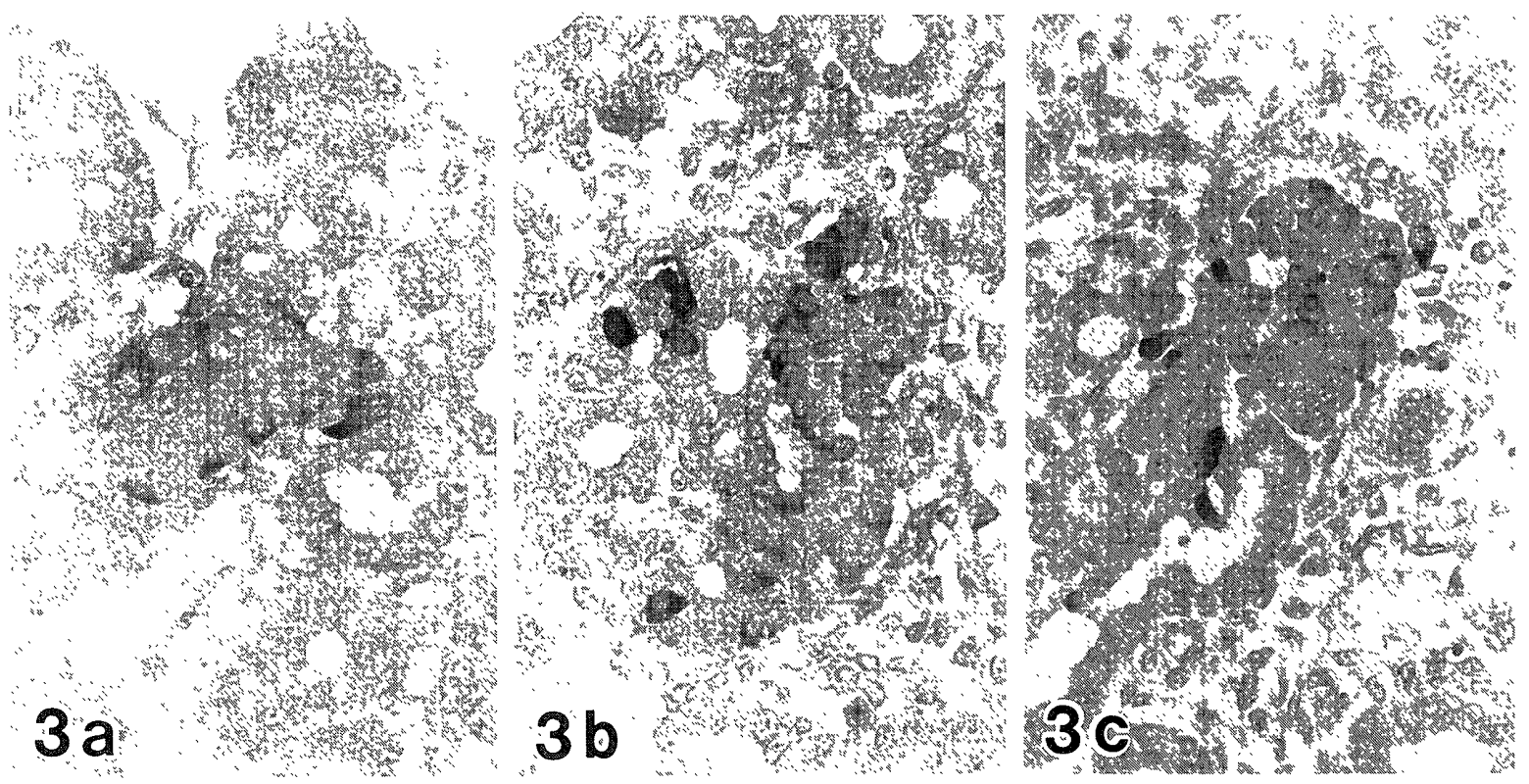

Fig. 3. Photomicrographs of 16-day fetal pancreases (a: control group, b: ADX group, c: ADX+cort group, $\times 333$ ). Almost no differences are seen among the 3 groups in distributional pattern.

appearance of fetal pancreatic islets approximately on day 12 of gestation. Thus, at the time of the appearance of islet cells, maternal adrenal steroid hormones would have been almost eliminated. Also, fetal adrenal cortex would not secrete any trace of its own hormones until day 16 , since plasma corticosterone is first detected on day 17 [2]. Under such a circumstance with neither maternal nor fetal adrenocortical hormones, it was found that insulin-positive cells were clearly retarded in development. This situation was compensated with maternal corticosterone therapy. Accordingly, the results were in good favor of the view that maternal adrenocortical hormones, glucocorticoids in particular, can accelerate the early development of pancreatic islets, particularly B-cells. A contradictory opinion may be put forward in that maternal surgery and/or lack of adrenocortical hormones may cause a delay in fetal body weight gain, resulting in maldevelopment of fetal Bcells. This opinion, however, can be ruled out, since the present results showed that fetal body weights following maternal adrenalectomy did not decline significantly as compared with non-operated controls.

In the present study, it is to be noted in particular that the influence of maternal adrenalectomy did not extend to day 16 on which day the collective volume of B-cells was all the same in the 3 groups tested. Even on the preceding day 15 , furthermore, the effect of maternal adrenalectomy was somewhat lessened, and nevertheless, maternal corticosterone therapy failed to work compensatorily for the decline in the collective volume of B-cells. This situation might be ascribed to the fetal adrenal cortex which would secrete so minute amount of cortical hormones as to be not detectable by available methods, though plasma corticosterone has been first detected on day 17 [2]. In fact, it has been reported that 14-day fetal adrenals cultured in vitro can respond to $\mathrm{ACTH}$ added in the medium, in terms of increase in size of cortical cells [14], and that 14-day fetal pituitary glands can exert some corticotropic influence on the co-transplanted 17-day adrenals [15].

In relation to this, it would be pertinent to mention that several studies heretofore reported were concerned with no effect of glucocorticoids on the development of fetal pancreatic B-cells beyond day 16 of gestation, particularly near the end of fetal life, though dealing with in vitro results $[8-11,13]$. These studies further showed a line of evidence that glucocorticoids would exert some inhibitory actions on the secretion of insulin from B-cells. Accordingly, it seems that, beyond day 16 , glucocorticoids influence the glucose sensitivity rather than the growth of B-cells; in other words, glucocorticoids would act on functioning of the differentiated B-cells.

It can be concluded that adrenocortical hormones would aid the early development and control the later functioning of B-cells.

ACKNOWLEDGMENT. This study was supported in part by a Grant-in-Aid for Scientific Research from the Ono Pharmaceutical Co., Ltd.

\section{REFERENCES}

1. Clark, W. R. and Rutter, W. J. 1972. Synthesis and accumulation of insulin in the fetal rat pancreas. Develop. Biol. 29: 468-481.

2. Cohen, A. 1973. Plasma corticosterone concentration in the foetal rat. Horm. Metab. Res. 5: 66.

3. Dupouy, J. P., Coffigny, H., and Magre, S. 1975. Maternal and foetal corticosterone levels during late pregnancy in rats. J. Endocrinol. 65: 347-352.

4. Fujii, S. 1979. Development of pancreatic endocrine cells in 
the rat fetus. Arch. Histl. Jpn. 42: 467-479.

5. Han, J. H., Rall, L., and Rutter, W. J. 1986. Selective expression of rat pancreatic genes during embryonic development. Proc. Natl. Acad. Sci. U.S.A. 83: 110-114.

6. Hard, W. L. 1944. The origin and differentiation of the alpha and beta cells in the pancreatic islets of the rat. Am. J. Anat. 75: 369-403.

7. Kamoun, A. 1970. Activité cortico-surrénale au cours de la gestation, de la lactation et du développement pré et postnatal chez le rat. I. Concentration et cinétique de dispartion de la corticostérone. J. Physiol. 62: 5-32.

8. McEvoy, R. C. 1980. Fetal and neonatal rat pancreas in organ culture: age-related effects of corticosterone on the development of the islet cells. Am. J. Anat. 157: 319-327.

9. McEvoy, R. C. and Herge, O. D. 1976. Foetal rat pancreas in organ culture: effects of media supplementation with various steroid hormones on the acinar and islet components. Differentiation 6: 105-111.

10. McEvoy, R. C., Herge, O. D., and Lazarow, A. 1976. Foetal rat pancreas in organ culture: effects of corticosterone on the acinar and islet cell components. Differentiation 6: 17-26.

11. McEvoy, R. C., Leung, P. E., and Goggins, J. A. 1981. Tis- sue culture of fetal rat islets: corticosterone promotes $D$ cell maintenance and function. Endocrinology 108: 2277-2282.

12. Parsa, I., Marsh, W. H., and Fitzgerald, P. 1969. Pancreas acinar cell differentiation. I. Morphologic and enzymatic comparisons of embryonic rat pancreas and pancreatic anlage grown in organ culture. Am. J. Pathol. 57: 457-487.

13. Wells, L. J., Erlandsen, S. L., and Eguchi, Y. 1968. Development of pancreases and adrenals of rat embryos in organ culture. Anat. Rec. 160: 201-206.

14. Yamamoto, M., Arishima, K., and Eguchi, Y. 1986. The sensitivity of the fetal rat adrenal gland to adrenocorticotropic hormone in vivo and in vitro. Biol. Neonate 50: 48-54.

15. Yamamoto, M., Arishima, K., Takizawa, T., Shirai, M., and Eguchi, Y. 1992. Sensitivity of the fetal rat pituitary-adrenal system to corticotropin-releasing factor in organ culture. Acta Anat. 145: 88-92.

16. Yoshinari, M. and Daikoku, S. 1982. Ontogenetic appearance of immunoreactive endocrine cells in rat pancreatic islets. Anat. Embryol. 165: 63-70.

17. Zarrow, M. X., Philott, J. E., and Denenberg, V. H. 1970. Corticosterone passes from mother to young through placenta. Nature (Lond.) 226: 1058-1059. 